\title{
POLA PENGGUNAAN OBAT UNTUK PENDERITAGAGAL GINJAL AKUT DI INSTALASI RAWAT INAP RUMAH SAKIT UMUM PUSAT (RSUP) DR. SARDJITO YOGYAKARTA TAHUN 1997-2001
}

\author{
Suci Hanifah \\ Jurusan Farmasi Universitas Islam Indonesia
}

\begin{abstract}
Drug Utility Review for ARF' patients of Internal Unit, Sardjito's hospital was examed. It involved 109 ARF's patients. Medical Record Unit reported that this number was $0,12 \%$ of all disese i.e. 93.445 case in 2001. The level was $93^{\text {rd }}$ from 945 kind of disease. It was studied by nonanalitical descriptive design. using notes of Medical Record system. Collecting of data by retrospektive methode.

This research was aimed to study the Drug Utility Review for ARF's patients, especially to study ; drug variation included kind and class of drugs, route of administration, variation drug number, length of stay, and regimen dosage of drugs. To complete it, mortality persentaged was reported.

The result of the study showed that ARF's patients got so many variation of drugs. Using of antibiotic, diuretic, and electrolit was the most case. It conformed to Health Care Standard in Sardjito's hospital. The others was aimed to simptomatical drugs i.e. antihypertensi, cardioasculer drugs, analgetic, antiemetic, multivitamin, laxan etc. It depended on symptoms and complication of patients. Variation of number between 1-24. The average number was 7,7 drugs. It tended to use new generation of antibiotic and combinatins antibiotic, as indicator of extravagant prescibing. Route of administratin by orally in most case and $38 \%$ by injection. Injection route so indicate extravagant prescibing except on emergency care. The others used by sublingual and suppositoria. Length of stay averaged 12,52 days. Mortality persentaged was $22 \%$.
\end{abstract}

Key words : Drug Utility Review, ARF, Medical Record,Extravagant Prescribing.

\section{PENDAHULUAN}

Gagal ginjal akut masih saja menjadi penyakit yang meningkat terus prevalensinya. Di mana gagal ginjal akut bisa ditemukan dalam praktik sehari-hari maupun pada penderita yang dirawat di rumah sakit. Insidennya sekitar 0,38 \% dari penderita yang dirawat di rumah sakit (Dewayani, 2000).

Saat ini rumah sakit adalah bagian integral dari keseluruhan sistem pelayanan kesehatan di mana Departemen Kesehatan RI menggariskan bahwa rumah sakit mempunyai tugas untuk melaksanakan upaya penyembuhan dan pemulihan yang dilaksanakan secara serasi dan terpadu (Lukas, 1999). Dalam hal ini ketepatan penggunaan obat menjadi unsur penting untuk mewujudkan derajat kesehatan yang optimal, meliputi tepat dosis, tepat indikasi, tepat cara pemakaian dan tepat penderita serta waspada efek samping. Medical record system sebagai bagian dari pelayanan rumah sakit menjadi bahan masukan data yang valid untuk evaluasi pola penggunaan obat (Hassan, 1986). 
Tujuan dari evaluasi penggunaan obat ini adalah mengetahui macam obat, cara pemberian, variasi regimen (tunggal atau majemuk), variasi lama perawatan, sehingga dapat digunakan sebagai salah satu sumber informasi tentang pola penggunaan obat untuk penderita gagal ginjal akut.

dan sebagai salah satu bahan acuan dalam peningkatan mutu pelayanan medik dalam pengobatan gagal ginjal akut.

Gagal ginjal akut adalah sindroma klinik dengan aneka macam sebab yang ditandai oleh penurunan fungsi ginjal secara mendadak dengan akibat hilangnya kemampuan ginjal untuk mempertahankan homeostasis tubuh (Alatas, 1999) dan ditandai dengan penurunan filtrasi glomeruler (GFR), oliguria (produksi urin $<400 \mathrm{ml} / 24 \mathrm{jam}$ ) dan retensi substansi yang berbahaya yang dalam keadaan normal dikeluarkan lewat urin (Anonim, 2000).

Manajemen terapi standar yang tertera dalam Standar Pelayanan Medik RSUP DR. Sardjito :

1. Semua kasus gagal ginjal akut harus dirawat di rumah sakit yang mempunyai fasilitas untuk menangani ( adanya mesin hemodialisis, atau setidak-tidaknya ada fasilitas untuk peritoneal dialisis )

2. Secara umum, mencari dan mengatasi kasus pra dan postrenal ( keseimbangan cairan dan elektrolit ), mencari bukti-bukti iskemia, nefrotoksin atau penyakit parenkimal ginjal, dan mengusahakan curah urin bertambah dengan pemberian cairan atau obat furosemid.

3. Terapi konservatif yang dilakukan meliputi, lepas daur kateter jika terpasang, mencatat masukan dan keluaran cairan, mengukur berat badan setiap hari ( jika memungkinkan ), Pembatasan cairan $400 \mathrm{ml}+$ keluaran cairan sehari sebelumnya,

4. Memberikan antibiotik profilaksi jika diperlukan.

5. Secara khusus. Indikasi terapi aktif masih kontroversial. Ada yang menganjurkan untuk dilakukan sedini mungkin. Karena biaya relatif tingi, sebaiknya baru dilakukan bila terapi konservatif tidak berhasil.

6. Lama perawatan umumnya satu bulan dengan pemulihan 2 minggu dan keluar dalam keadaan sembuh sempurna.

\section{METODOLOGI PENELITIAN}

Bahan Penelitian

Bahan penelitian adalah kartu rekam medik untuk penderita Instalasi rawat Inap RSUP DR. Sardjito dengan diagnosis utama gagal ginjal akut selama 1997-2001.

\section{Jalannya Penelitian}

Penelitian dilakukan dengan 2 tahap. Tahap pertama adalah penelusuran data. Tahap kedua adalah identifikasi pola penggunaan obat.

\section{Tahap penelusuran data}

Proses penelusuran data dimulai dari observasi la-poran unit rekam medik secara retrospektif untuk kasus-kasus dengan diagnosis utama GGA selama tahun 1997-2001. Laporan dari unit rekam medik berupa daftar nomor register dari para penderita. Nomor register digunakan untuk mengumpulkan kartu status penderita. Dari kartu status ini dibuat salinan resep obat yang digunakan dengan cara membuat tabulasi yang meliputi: nomor register, umur, diagnosa akhir, komplikasi, macam obat yang digunakan, dosis obat yang digunakan, cara pemberian, lama perawatan serta kondisi pasien saat pulang.Pengelompokan dibuat berdasarkan penyebab dan umur. Hal ini di-maksudkan untuk membedakan penderita balita (0-5 tahun), anak-anak (5-12 tahun), dan dewasa (12-65 tahun), dan usia lanjut (>65 tahun). Pengelompokan penyebab dibagi menjadi GGA prarenal, renal, pascarenal, dan dalam pela-cakan.

2. Tahap identifikasi pola penggunaan obat pada GGA 
Pada tahap ini dilakukan identifikasi melalui tabel tabel yang dibuat. Kemudian dibandingkan dengan standar pelayanan medik dari RSUP Dr. Sardjito.

\section{HASIL DAN PEMBAHASAN}

Deskripsi umum hasil penelitian akan disajikan dalam 2 kategori, yaitu berdasarkan pada proses penelusuran data, dan identifikasi kasus yang menarik dan membandingkannya dengan standar RSUP DR. Sardjito.

a. Proses penelusuran data

Proses penelusuran data dilakukan dengan jalan mengamati satu per satu kartu status atau rekam medik penderita. Dimulai dari nomor register yang terdapat dalam laporan dari unit rekam medik pada bulan Januari 1997 sampai Desember 2001. Dari penelusuran data ini diperoleh kasus sebanyak 111 kasus . Dan dari hasil identifikasi lanjut hanya 109 dengan diagnosis utama gagal ginjal akut. Dari jumlah ini kemudian dianalisis untuk melihat pola penggunaan obatnya. Ada status yang ditulis secara lenkap dan jelas dan ada juga yang tidak.

\section{(a) Golongan Obat yang Digunakan}

Tabel I. Persentase Golongan Obat yang Digunakan pada Penderita GGA di Instalasi Rawat Inap RSUP Dr. Sardjito 1997-2001

\begin{tabular}{|c|c|c|}
\hline No & Golongan Obat & $\begin{array}{l}\text { Persentase } \\
\text { penggunaan }\end{array}$ \\
\hline 1. & Elektrolit & $96,33 \%$ \\
\hline 2. & Antibiotik & $78 \%$ \\
\hline 3. & Diuretik & $56,9 \%$ \\
\hline 4. & Antianemia & $43,11 \%$ \\
\hline 5. & Obat saluran pencernaan & $43,11 \%$ \\
\hline 6. & Vitamin & $36,7 \%$ \\
\hline 7. & Antihipertensi & $36,7 \%$ \\
\hline 8. & Antirematik & $33 \%$ \\
\hline 9. & Suplemen & $24,11 \%$ \\
\hline
\end{tabular}

(b) Cara Pemberian Obat

Tabel II. Macam dan Persentase Cara Pemberian Obat Berdasarkan Kelompok Umur dan Penyebab pada Penderita GGA di Instalasi Rawat Inap RSUP Dr. Sardjito 1997-2001

\begin{tabular}{|c|c|c|c|c|c|c|}
\hline NO & $\begin{array}{c}\text { Kel.Umur } \\
\text { (tahun) }\end{array}$ & penyebab & P.O & injeksi & S.L & Suppo \\
\hline
\end{tabular}




\begin{tabular}{|c|c|c|c|c|c|c|}
\hline \multirow[t]{2}{*}{1.} & $0-5$ & prarenal & $85,7 \%$ & $14,3 \%$ & - & - \\
\hline & & renal & $63 \%$ & $37 \%$ & - & - \\
\hline 2. & $5-12$ & renal & $82,2 \%$ & $13,7 \%$ & $2,7 \%$ & $1,36 \%$ \\
\hline \multirow[t]{4}{*}{3.} & $12-65$ & prarenal & $54,4 \%$ & $44,7 \%$ & - & $0,9 \%$ \\
\hline & & renal & $45,7 \%$ & $54,3 \%$ & - & - \\
\hline & & pascarenal & $61,7 \%$ & $38,3 \%$ & - & - \\
\hline & & pelacakan & $45,7 \%$ & $54,3 \%$ & - & - \\
\hline \multirow[t]{5}{*}{4.} & $>65$ & prarenal & $48,3 \%$ & $51,7 \%$ & - & - \\
\hline & & renal & $55,2 \%$ & $44,8 \%$ & - & - \\
\hline & & pascarenal & $50 \%$ & $51,4 \%$ & - & - \\
\hline & & pelacakan & $48,6 \%$ & $51,4 \%$ & - & - \\
\hline & RataRata & & $58,2 \%$ & $38 \%$ & $2,7 \%$ & $1,13 \%$ \\
\hline
\end{tabular}

(c) Variasi Jumlah Obat

Tabel III. Variasi Jumlah Obat Berdasarkan Kelompok Umur dan Penyebab pada Penderita GGA di Instalasi Rawat Inap RSUP Dr. Sardjito 1997-2001

\begin{tabular}{|c|c|c|c|c|c|}
\hline \multirow[t]{2}{*}{ NO } & \multirow[t]{2}{*}{ Kelompok Umur } & \multirow[t]{2}{*}{ Penyebab } & \multicolumn{3}{|c|}{ Jumlah Obat } \\
\hline & & & minimum & maksimum & rata2 \\
\hline \multirow[t]{2}{*}{1.} & $0-5$ tahun & prarenal & 6 & 8 & 7 \\
\hline & & renal & 8 & 10 & 9 \\
\hline 2. & 5-12 tahun & renal & 1 & 18 & 7,9 \\
\hline \multirow[t]{4}{*}{3.} & $12-65$ tahun & prarenal & 3 & 14 & 7,7 \\
\hline & & renal & 5 & 11 & 7,1 \\
\hline & & pascarenal & 2 & 24 & 8,9 \\
\hline & & pelacakan & 2 & 11 & 5,8 \\
\hline \multirow[t]{5}{*}{4.} & $>65$ tahun & prarenal & 3 & 11 & 7,25 \\
\hline & & renal & 4 & 10 & 7,25 \\
\hline & & pascarenal & 5 & 13 & 8,3 \\
\hline & & pelacakan & 3 & 8 & 6,8 \\
\hline & & & 1 & 24 & 7,7 \\
\hline
\end{tabular}

(d) Variasi jumlah antibiotika 
Tabel IV. Variasi Jumlah Antibiotika yang Digunakan Berdasarkan Kelompok Imur dan Penyebab pada Penderita GGA di Instalasi Rawat Inap RSUP. Dr. Sardjito 1997-2001

\begin{tabular}{|l|l|c|c|c|c|c|}
\hline \multirow{2}{*}{ No } & \multirow{2}{*}{ Kelompok Umur } & \multicolumn{5}{|c|}{ Jumlah Antibiotika yang digunakan } \\
\cline { 3 - 7 } & $\begin{array}{c}0 \\
\text { antibiotika }\end{array}$ & $\begin{array}{c}1 \\
\text { antibiotika }\end{array}$ & $\begin{array}{c}2 \\
\text { antibiotika }\end{array}$ & $\begin{array}{c}>2 \\
\text { antibiotika }\end{array}$ & $\begin{array}{c}\text { Jumlah } \\
\text { Pasien }\end{array}$ \\
\hline 1. & $0-5$ tahun & - & - & 3 & 2 & 5 \\
2. & $5-12$ tahun & 1 & 3 & 3 & 3 & 10 \\
3. & $12-65$ tahun & 19 & 31 & 16 & 4 & 71 \\
4. & $>65$ tahun & 4 & 7 & 9 & 3 & 23 \\
\hline
\end{tabular}

(e) Dosis yang digunakan

Dosis yang digunakan pada penderita GGA khususnya obat yang persentase pemakaiannya besar yaitu diuretik dan antibiotika.

Tabel V. Dosis Antibiotika dan Furosemid yang Digunakan pada Penderita GGA di Instalasi Rawat Inap RSUP Dr. Sardjito 1997-2001

\begin{tabular}{|c|c|c|c|c|c|}
\hline \multirow{2}{*}{ No } & \multirow{2}{*}{ Macam Obat } & \multicolumn{4}{|c|}{ Dosis Obat yang digunakan pada Kelompok Umur (tahun) } \\
\hline & & $0-5$ & $5-12$ & $12-65$ & $>65$ \\
\hline 1. & Antibiotika & & & & \\
\hline a. & Ampisilin & $4 \times 250$ & $4 \times 500$ & $1 \mathrm{~g} / 6 \mathrm{j}$ & $1 \mathrm{~g} / 6 \mathrm{j}$ \\
\hline & & $4 \times 100$ & $4 \times 250$ & & \\
\hline & & & $3 \times 500$ & & \\
\hline b. & Amoksisilin & & $3 \times 250$ & $3-4 \times 500$ & $3 \times 500$ \\
\hline c. & Inj. PP & 300.000 & & 1,2-1,5juta & 1,2juta U/6j \\
\hline & & $\mathrm{U} / 6 \mathbf{j}$ & & $U / 6 j$ & \\
\hline d. & Sefuroksim & & & $1 \mathrm{~g} / 8-12 \mathrm{j}$ & \\
\hline e. & Sefotaksim & $2 \times 330$ & & $1 g / 12-24 j$ & $1 \mathrm{~g} / \mathrm{h}$ \\
\hline f. & Sefipim & & & & $1 g / 12-24 j$ \\
\hline g. & Seftriakson & $2 \times 220$ & & 1g/12jam & \\
\hline & & & & $2 \times 250$ & \\
\hline h. & Sefiksim & & $2 \times 15$ & $2 \times 100$ & $2 \times 500$ \\
\hline i. & Siprofloksasin & & & $2 \times 500$ & 1g/24jam \\
\hline j. & Sefradin & & & & \\
\hline k. & Na Sefaperazon & & & $3 \times 500$ & \\
\hline & & & $1 g / 12 j$ & & \\
\hline
\end{tabular}




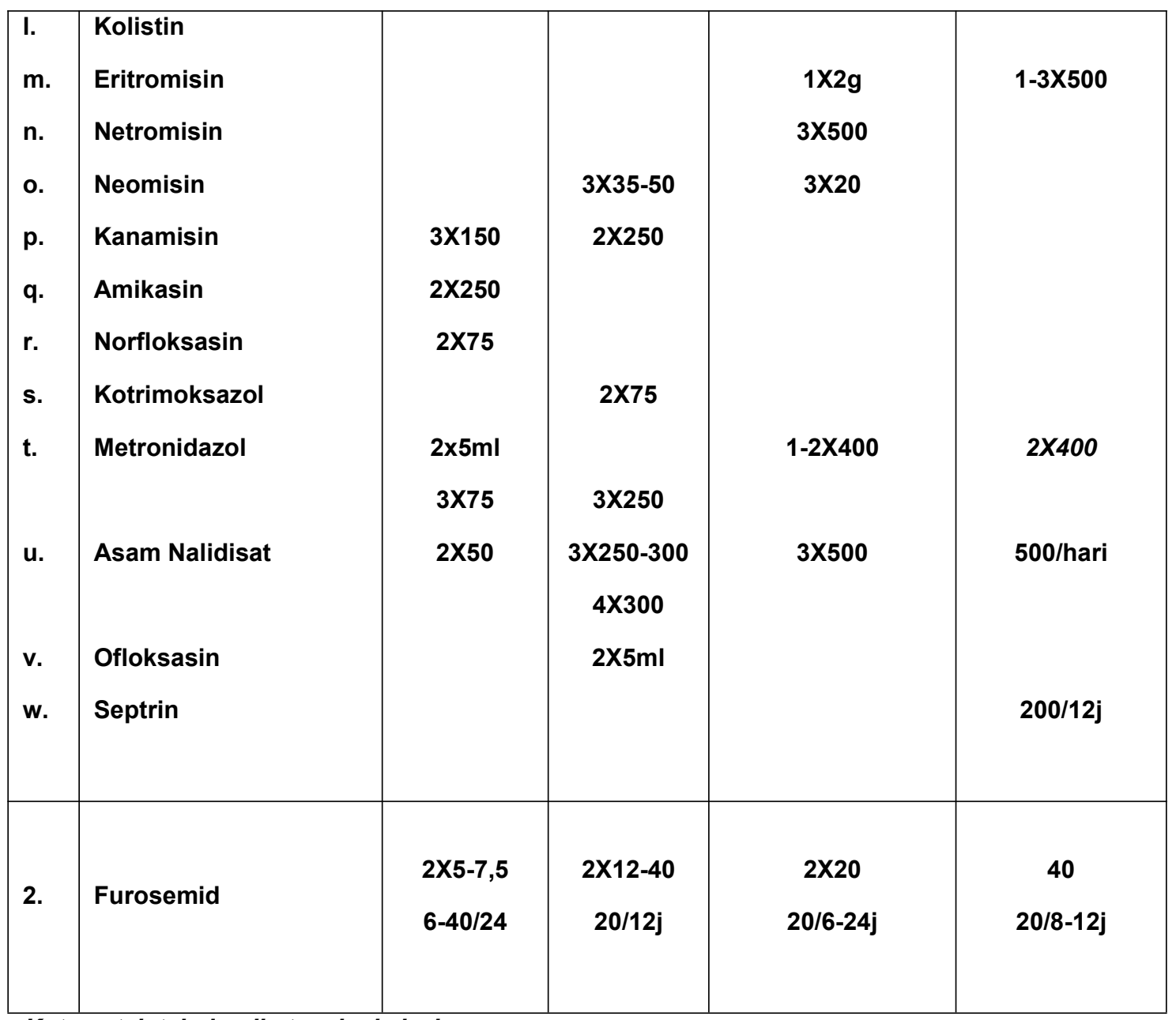

Ket : cetak tebal : di atas dosis lazim

cetak miring : di bawah dosis lazim

(f) Variasi Lama Perawatan

Tabel VI. Variasi Lama Perawatan Berdasarkan Penyebab dan Kelompok Umur pada Penderita GGA di Instalasi Rawat Inap RSUP. Dr. Sardjito 1997-2001

\begin{tabular}{|l|l|l|r|r|r|r|}
\hline No & $\begin{array}{l}\text { Umur } \\
\text { (tahun) }\end{array}$ & Penyebab & $\begin{array}{l}\text { Jumlah } \\
\text { Kasus }\end{array}$ & $\begin{array}{l}\text { Terce } \\
\text { pat }\end{array}$ & $\begin{array}{l}\text { Terla } \\
\text { ma }\end{array}$ & Rata-Rata (hari) \\
\hline 1 & $0-5$ & prarenal & 2 & 2 & 7 & 4,5 \\
& & renal & 3 & 5 & 7 & 6,3 \\
\hline 2 & $5-12$ & renal & 10 & 1 & 27 & 14,1 \\
\hline & & prarenal & 15 & 4 & 24 & 8,9 \\
3 & $12-65$ & renal & 16 & 1 & 28 & 9,5 \\
& & pascarenal & 28 & 1 & 97 & 19 \\
& & pelacakan & 12 & 1 & 14 & 6 \\
\hline 4 & $>65$ & prarenal & 8 & 10 & 16 & 8,6 \\
\hline
\end{tabular}




\begin{tabular}{|l|l|l|l|l|l|l|}
\hline & renal & 4 & 1 & 10 & 5,75 \\
pascarenal & 6 & 5 & 46 & 21 \\
pelacakan & 5 & 1 & 26 & 11 \\
\hline & & 109 & 1 & 97 & 12,2 \\
\hline
\end{tabular}

\section{(g) Distribusi keadaan pulang}

Tabel VII. Distribusi Keadaan Pulang Berdasarkan Penyebab dan Kelompok Umur pada Penderita GGA di Instalasi Rawat Inap RSUP Dr. Sardjito 1997-2001

\begin{tabular}{|c|c|c|c|c|c|c|}
\hline \multirow[b]{2}{*}{ No } & \multirow[b]{2}{*}{ Penyebab } & \multirow{2}{*}{$\begin{array}{l}\text { Kel. Umur } \\
\text { (tahun) }\end{array}$} & \multirow{2}{*}{$\begin{array}{l}\text { Jumlah } \\
\text { kasus }\end{array}$} & \multicolumn{3}{|c|}{ Jumlah Penderita dalam Keadaan Pulang } \\
\hline & & & & $\begin{array}{l}\text { Sembuh/ } \\
\text { membaik }\end{array}$ & $\begin{array}{c}\text { Pulang } \\
\text { paksa }\end{array}$ & Meninggal \\
\hline 1. & Prarenal & $\begin{array}{l}0-5 \\
12-65 \\
>65\end{array}$ & $\begin{array}{c}2 \\
15 \\
8\end{array}$ & $\begin{array}{c}1 \\
13 \\
5\end{array}$ & $\begin{array}{l}- \\
1 \\
-\end{array}$ & $\begin{array}{l}1 \\
1 \\
3\end{array}$ \\
\hline 2. & Renal & $\begin{array}{l}0-5 \\
5-12 \\
12-65 \\
>65\end{array}$ & $\begin{array}{c}3 \\
10 \\
16 \\
4\end{array}$ & $\begin{array}{l}- \\
6 \\
5 \\
1\end{array}$ & $\begin{array}{l}1 \\
2 \\
6 \\
2\end{array}$ & $\begin{array}{l}2 \\
2 \\
5 \\
1\end{array}$ \\
\hline 3. & Pascarenal & $\begin{array}{l}12-65 \\
>65\end{array}$ & $\begin{array}{c}28 \\
6\end{array}$ & $\begin{array}{c}18 \\
5\end{array}$ & $\begin{array}{l}7 \\
-\end{array}$ & $\begin{array}{l}3 \\
1\end{array}$ \\
\hline 4. & Pelacakan & $\begin{array}{l}12-65 \\
>65\end{array}$ & $\begin{array}{l}12 \\
5\end{array}$ & $\begin{array}{l}5 \\
3\end{array}$ & $\begin{array}{l}4 \\
-\end{array}$ & $\begin{array}{l}3 \\
2\end{array}$ \\
\hline & Jumlah & & 109 & 62 & 23 & 24 \\
\hline & Persentase & & $100 \%$ & $56,9 \%$ & $21,1 \%$ & $22 \%$ \\
\hline
\end{tabular}

Penderita GGA di Instalasi Rawat Inap RSUP Dr. Sardjito selama tahun 1997-2001 secara umum menggunakan obat-obatan golongan antibiotika, elektrolit, diuretika, multivitamin, obat kardiovaskuler, antihipertensi, obat saluran pencernaan termasuk pencahar dan berbagai obat tambahan lainnya tergantung gejala atau komplikasi yang dialami penderita. Dari golongan-golongan obat yang digunakan, pengobatan yang sesuai dengan Standar Pelayanan Medik RSUP Dr.Sardjito adalah elektrolit sebesar $96,33 \%$, antibiotik $78 \%$, dan diuretik furosemid $56,9 \%$. Golongan obat lainnya hanya berfungsi simtomatik. Terapi konser-vatif lainnya yang disebutkan dalam Standar Pelayanan Pada kelompok umur 12-65 tahun mendapatkan obat dengan macam golongan yang terbanyak yaitu antara 9-16 golongan. Sedangkan pada kelompok umur 0-5 tahun relatif paling sedikit dengan 9-11 macam golongan.

Macam elektrolit yang digunakan seperti pada Standar Pelayanan Medik RSUP Dr. Sardjito adalah, pengikat fosfat, pengatasan hiperkalemia, dan asidosis. Pengikat fosfat yang banyak digunakan adalah $\mathrm{CaCO}_{3}$. Selain sebagai pengikat fosfat, $\mathrm{CaCO}_{3}$ juga dapat berfungsi untuk pengatasan asidosis, disamping dengan penggunaan natrium bikarbonat. Hiperkalemi banyak diatasi dengan kalsium glukonat, natrium bikarbonat, dan pemberian glukosa serta insulin. Selain seperti yang tertera pada Standar 
Pelaya-nan Medik juga digunakan Ringer laktat untuk menjaga keseimbangan ion $\mathrm{Na}^{+}, \mathrm{Cl}^{-}, \mathrm{K}^{+}, \mathrm{Ca}^{++}$, dan $\mathrm{HCO}_{3}{ }^{-}, \mathrm{NaCl}$ untuk keseimbangan ion $\mathrm{Na}^{+}, \mathrm{KCL}$ dan AsparK untuk keseimbangan ion $\mathrm{K}^{+}$.

Macam antibiotika yang digunakan sampai 23 macam. Antibiotika ampisilin banyak digunakan pada semua kelompok umur. Ada kecenderungan penggunaan antibiotika generasi ketiga dari turunan sefalosporin yang harganya relatif mahal. Penggunaan obat yang mahal dapat mengarah pada peresepan yang tidak rasional (extravagant prescribing).

Penggunaan obat pada penderita gagal ginjal akut ini 38\% menggunakan cara parenteral melalui injeksi. Cara pemberian melalui injeksi ini terutama untuk elektrolit, antibiotika, dan diuretika furosemid. Hal ini kemungkinan disebabkan kondisi penderita yang gawat dan tidak memungkinkan untuk diberikan pengobatan secara peroral. Meskipun sebenarnya pengobatan secara injeksi relatif lebih mahal sehingga ada kecenderungan penggunaan yang tidak rasional dan sebaiknya dihindari pada anak-anak karena menyebabkan trauma. Pada penderita GGA di Instalasi Rawat Inap RSUP Dr. Sardjito 1997-2001, persentase cara pem-berian dengan injeksi pada kelompok umur anak-anak relatif lebih kecil dibandingkan pada kelompok umur dewasa.

Variasi jumlah obat yang digunakan rata-rata 7,7 obat. Meskipun tidak ada keterangan apakah penggunaannya secara bersamaan atau berjarak waktu, namun karena pada umumnya penggunaan dosis ganda, sehingga penggunaan jumlah obat yang banyak tetap saja dapat menimbulkan interaksi farmakologis. Untuk mencapai pengobatan yang rasional, penggunaan obat secara majemuk sedapat mungkin dihindari. Penggunaan obat kombinasi (ganda atau lebih), menuntut kehati-hatian yang lebih tinggi dan kontrol yang lebih cermat, mengingat ada kemungkinan terjadinya interaksi obat.

Penggunaan antibiotika ganda banyak diberikan pada penderita GGA di Instalasi Rawat Inap RSUP Dr. Sardjito selama 1997-2001. Menurut Sastramihardja (1997 b) antibiotika kombinasi diperlukan jika kriteria indikasinya terpenuhi yaitu, untuk infeksi campuran (memperlebar spektrum), infeksi berat yang penyebab spesifiknya belum diketahui (memperlebar spektrum), meningkatkan aktivitas antibiotika, mencegah/memperlambat terjadinya resistensi bakteri (pada kasus tuberkulosa). Pemakaian antibiotik kombinasi ini menunjukkan, tidak hanya profilaksis yang dituju namun juga untuk pengobatan infesi yang menyertai. Perlu diteliti lebih lanjut mengenai alasan penggunaan antibiotika majemuk.

Pola penggunaan obat pada gagal ginjal akut ini menunjukkan bahwa dosis antibiotika yang digunakan, sebagian besar masih menggunakan dosis lazim kondisi tubuh normal dengan beberapa kasus berada di atas dan dibawah dosis lazim. Belum digunakannya penyesuaian dosis pada sebagian besar penderita penyakit gagal ginjal akut ini, menuntut penelitian dan perhatian lebih lanjut.

Pada penggunaan furosemid terlihat bahwa dosis yang digunakan beragam dari mulai $40 \mathrm{mg}$ sampai $160 \mathrm{mg}$ sehari pada usia dewasa, dan sudah ada penyesuaian dosis untuk anak dan geriatri. Penggunaan dosis tinggi furosemid ini dianjurkan, untuk mempercepat pengatasan oliguri, dengan syarat tidak melebihi dosis maksimal sebesar $500 \mathrm{mg} / \mathrm{jam}$.

Lama pemakaian antibiotika berkisar antara 1-23 hari, dengan rata-rata 5,2 hari. Lama pemakaian ini tidak sesuai dengan standar yang seharusnya yaitu antara 3-5 hari atau 7-10 hari untuk infeksi berat (Katzung dan Lofholm, 1998). Lama terapi antibiotika yang berbeda-beda untuk maksud hasil yang efektif dan mencegah kekambuhan, memperhatikan pertimbangan-pertimbangan antara lain kesanggupan bakteri dalam melawan atau mengurangi pertahanan tubuh yang normal, lokasi infeksi dan selektivitas bakteri terhadap antibiotika, aktivitas primer terhadap bakteri, dan mekanisme terjadinya resistensi (Sastramihardja, 1997 ${ }^{\mathrm{b}}$ ). Perlu ditelusur lebih lanjut mengenai pemakaian antibiotika dalam waktu yang singkat, hanya 1 atau 2 hari saja, apakah karena tujuan profilaksis, resistensi, reaksi alergi, atau yang lainnya, juga pemakaian dalam waktu yang sangat lama sampai 23 hari.

Lama perawatan berkisar antara 1 sampai 97 hari, dengan rata-rata 12,52 hari. Hal ini lebih kecil dari Standar Pelayanan Medik RSUP Dr Sardjito yang umumnya 1 bulan, dengan lama pemulihan sekitar 2 minggu. Hal ini dapat dikaji lebih lanjut dengan mempertimbangkan per-sentase keadaan pasien pulang paksa yang cukup tinggi juga yaitu $21 \%$. Hal tersebut menunjukkan ada kemungkinan terapi yang dilakukan belum selesai, sehingga lama perawatan menjadi lebih singkat. Nilai rata-rata lama perawatan 12,52 hari ini, lebih besar dari rata-rata lama perawatan untuk semua kasus di RSUP Dr. Sarjito yaitu 9,02 hari.

Tingkat kematian yang cukup tinggi dengan angka 22\% dan angka pulang paksa sebesar $21 \%$, dapat dijadikan sebagai salah satu tolok ukur pelayanan. Selain itu perlu diteliti lebih lanjut penyebab kematiannya, apakah faktor keterlambatan, keparahan penyakit, terapi yang tidak bagus, ketidakmampuan penderita mengikuti terapi yang distandarkan sehingga pengobatan menjadi tidak 
tuntas, atau faktor-faktor lainnya. Dari unit rekam medik RSUP Dr. Sardjito melaporkan bahwa penyebab kematian pada umumnya bukanlah gagal ginjal itu sendiri, dan hanya ada 1 kasus yang disebabkan oleh GGA selama tahun 1997-2001.

\section{KESIMPULAN DAN SARAN}

\section{Kesimpulan}

Berdasarkan hasil penelitian, maka dapat disimpul-kan beberapa hal,

1. Pola pengobatan pada penderita gagal ginjal akut (GGA) di Instalasi Rawat Inap RSUP Dr Sardjito 1997-2001 secara umum dengan cara :

a. Memperbaiki keadaan oliguri dengan diuretik furose-mid dosis besar.

b. Memperbaiki keseimbangan elektrolit

c. Mencegah dan mengobati infeksi yang muncul dengan antibiotik

Penggunaan obat diluar ketiga hal di atas, hanya bersi-fat simtomatik.

2. Penderita GGA di Instalasi Rawat Inap RSUP Dr. Sardjito selama 1997-2001 menggunakan terapi khusus yang sesuai dengan Standar Pelayanan Medik RSUP Dr. Sardjito seba-nyak, 96,33\% elektrolit, $78 \%$ antibiotika, dan $56,9 \%$ diuretik furosemid.

3. Terapi lain yang ditujukan untuk tujuan simtomatik dan tidak tercantum dalam Standar Pelayanan Medik, berupa antianemia $43,11 \%$, suplemen $24,11 \%$, obat saluran pencernaan $43,11 \%$, antiencok $33 \%$, antihipertensi $36 \%$, vitamin $36,7 \%$.

4. Cara pemberian : peroral $64,7 \%$, injeksi $38 \%$, sublingual $2,7 \%$, dan suppositoria $1,13 \%$.

5. Sebanyak 99\% kasus menggunakan obat kombinasi. Hanya ada 1 dari 109 kasus yang menggunakan obat tunggal.

6. Variasi jumlah obat yang digunakan berkisar antara 1-24 buah, dengan rata-rata 7,7 buah.

7. Variasi jumlah antibiotika yang digunakan berkisar an-tara 0-4 macam pada tiap-tiap kasus.

8. Dosis furosemid yang digunakan relatif lebih besar dari dosis lazim dan beragam mulai dari 40-160 mg per hari.

9. Dosis antibiotika yang digunakan sebagian besar menggunakan dosis lazim kondisi tubuh normal dan belum menggunakan penyesuaian dosis untuk penyakit ginjal.

10. Lama pemakaian antibiotika berkisar antara 1-23 hari, dengan rata-rata 5,2 hari

11. Lama perawatan rata-rata 12,52 hari, lebih cepat dari yang tercantum dalam Standar Pelayanan Medik.

12. Distribusi keadaan pulang meliputi : $56,9 \%$ sembuh/ membaik, $21,1 \%$ pulang paksa, $22 \%$ meninggal.

Saran

Berdasarkan hasil penelitian ini dapat diberikan saran sebagai berikut :

1. Dokter diharapkan dapat meningkatkan kepatuhannya dalam mengisi kartu rekam medik penderita.

2. Perlunya peran paramedis baik dokter maupun farmasis sebagai penanggung jawab posisi strategis Unit Rekam Medik sebagai bahan evaluasi dan analisis untuk mencari solusi yang tepat. 
3. Perlu adanya sensitivity test sebelum penggunaan antibiotika, sehingga dari hasilnya dapat digunakan sebagai penuntun perlu tidaknya penggunaan antibi-otika generasi baru.

4. Bagi peneliti lain dapat dilanjutkan di rumah sakit lain untuk mendapatkan gambaran penggunaan obat pada kasus yang sama dan meneliti lebih jauh mengenai kerasionalan penggunaan obat, misalnya dalam hal: ketepatan indikasi, ketepatan obat, dan ketepatan penderita

\section{DAFTAR PUSTAKA}

Abramson, J.H., 1991, Metode Survey dalam Kedokteran Komunitas, diterjemahkan oleh Akhid, Edisi Ketiga, 5-10, Gadjah Mada University Press, Yog-yakarta.

Alatas H., 1999, Gagal Ginjal Akut, dalam : Alatas H., Tambunan T., Trihono PP., penyunting. Buku Ajar Nefrologi Anak, 446-463, Jilid 2, Balai Penerbit FKUI, Jakarta.

Anonim, 1979, Farmakope Indonesia, Edisi ketiga, 959-970, Depkes RI, Jakarta.

Anonim, 1987, The Rational Use of Drugs dalam : Report of Conference of Experts Nairobi, (Nopember, 1985), 45-46, World Health Organization, Geneva.

Anonim, 1992ª Standar Pelayanan Rumah Sakit, 65-67 Direktorat Rumah sakit Umum dan Pendidikan, Depkes RI, Jakarta.

Anonim, 1992b, Pedoman Penggunaan Antibiotik Nasional, Edisi 1, Dirjen Pelayanan Medik, Depkes RI.

Anonim, 1993, How to Investigate Drug Use in Health Facilities; Selected Drug Use Indicators, 43-47, WHO, Geneva.

Anonim, 1998, Dokter-farmasis, Warta ISFI, Bandung, 3:6.

Anonim, 1999a, Profil Kesehatan Proponsi DIY, Departemen Kesehatan Propinsi DIY.

Anonim, 1999b, Rencana Pembangunan Kesehatan Menuju Indonesia Sehat 2010, 82, Departemen Kesehatan Republik Indonesia, Jakarta.

Anonim, 2000, Standar Pelayanan Medis RSUP DR. Sardjito, Medika, Fakultas Kedokteran Universitas Gadjah Mada, Yogyakarta.

Ashadi T, 1997, Pengupayaan Pengobatan yang Rasional, Medika, 23(1): 58-59 
Azwar, A., 1996, Pengantar Administrasi Kesehatan, Edisi ketiga, Binarupa Aksara, Jakarta.

De Vries, T.P.M., Henning, R.H., Hogerzeil,D.A., Fresle, 1998, Pedoman Penulisan Resep, diterjemahkan oleh Bustami, Z.S., 6-12, Program Obat Esensial, ITB Bandung.

Dewayani, S., 2000, Diagnosa dan Penatalaksanaan Gagal Ginjal Akut pada Anak, Medika, 26(10):642-646.

Farrington, K, 1993, Management of Acute Renal failure, cit Bakta, M., Suastika, K., 1999, Gawat Darurat dibidang Penyakit Dalam, EGC, Jakarta.

Gardjito, W., 1990, Antibiotika profilaksis-prinsip serta permasalahannya dalam Suryawati, dkk (Eds.), Pemilihan dan Pemakaian Antibiotika dalam Klinik, Yayasan Melati Nusantara, Yogyakarta.

Harrison, 1999, Prinsip-prinsip IImu Penyakit Dalam, diterjemahkan oleh Ahmad Asdie, Volume 3, 1425-1427, EGC, Jakarta

Hartono, A., 1995, Prinsip Diet Penyakit Ginjal, Cetakan IV, 35-40, Penerbit Arcan, Jakarta.

Hassan, W., 1986, Hospital Pharmacy, $5^{\text {th }}$ Ed, 48-49, Lea and Febiger, Philadelphia.

Inokuchi, S., Rector, F., 1996, Penyakit Ginjal, dalam, Ronardy, D., Penuntun Terapi Medis, diterjemahkan oleh Secilia, A., 67-93, EGC. Jakarta.

Katzung, B., Lofholm, D., 1998, Peresepan Rasional dan Penulisan Resep dalam: Farmakologi Dasar dan Klinik, diterjemahkan oleh Binawati, H., dkk, Edisi IV, Cetakan I, 1010-1011, EGC, Jakarta

Laurence, D., Bennet, P., Brown, M., 1997, Clinical Pharmacology, $8^{\text {th }}$ edition, 29-33, Churchil Living-stone

Lukas, S., 1999, Pelayanan Instalasi Farmasi Rumah Sakit Menyongsong 2000, Dexa Medika, 12:28.

Mansjoer, A., dkk., 1995, Kapita Selekta Kedokteran, Edisi III, jilid I, 529-531, Media aesculapius, Fakultas kedokteran UI, Jakarta.

Mindel, J.A., 1997, A Practical Approach to Acut Renal Failure, cit, Dewayani, S., Diagnosa dan Penatalaksanaan Gagal Ginjal Akut pada Anak, Medika, 2000, 26(10):642-646.

Parsoedi, I., Soewito, Ag., 1990, Gagal Ginjal Akut; dalam Soeparman, dkk (editor); Ilmu Penyakit Dalam, 341-345, Jilid II, Balai Penerbit FKUI, Jakarta. 
Patra, K., dkk., 2001, Informasi Spesialite Obat Indonesia, Edisi farmakoterapi, Volume XXXIII, ISFI, Jakarta.

Quick, J.D., 1982, Applied Management Science in Developing countries, Socio, Econ. Plan.

Quick, J.D., Hume, M.L., Rankin, J.R., 1997, Managing Drug Supply, $2^{\text {nd }}$ Ed, 422-429, Revised and Expanded, Kumarin Press, West Hartford.

Sastramihardja, S., $1997^{a}$, Penggunaan Obat yang Rasional di Tempat Pelayanan Kesehatan, Majalah Kedokteran Indonesia, 47(10); 532-536.

Sastramihardja, S., 1997 , Penggunaan Antibiotik yang Rasional, Cetakan pertama, 7-11, Yayasan penerbit IDI, Jakarta.

Shrier, R.W., 1993, Role of Calcium Channel Blockers in Pretection Againts Experimental Renal Injury, cit, Dewayani, S., Diagnosa dan Penatalaksaanaan Gagal Ginjal Akut pada Anak, Medika, 2000, 26(10): 642-646.

Sunatrio, S., 2000, Resusitasi Cairan, Edisi I, Media Aesculapius, Fakultas Kedokteran Universitas Indonesia, Jakarta.

Suryawati, S., 1997, Peran Farmasis dalam Peningkatan Kualitas Pelayanan Kesehatan di Rumah Sakit, Medika, 23(1):60Suwitra, K., 1999, Diagnosis dan Penatalaksanaan Gagal Ginjal Akut dalam; Bakta, M., Suastika, K.,(Eds.) Gawat Darurat di bidang Penyakit Dalam, 87-98, EGC, Jakarta.

Tyay, T. H., Rahardja, K., 1978, Obat-Obat penting, Khasiat Penggunaan, dan efek-efek sampingnya, Edisi keempat, 377, Jakarta

Widmann, K., Tinjauan Klinis atas Hasil Pemeriksaan laboratorium, diterjemahkan oleh Boedina, S., Gandasoebroto, R., Latu, J., Edisi 9, 521-537 Bagian Patologi Klinik FKUI/RSCM, Jakarta.

Zunilda, Setiawati, A., Suyatna, F.D., 1995, Pengantar Farmakologi, dalam

Ganiswara ,S., Farmakologi dan Terapi, Bagian Farmakologi, FKUI, Jakarta. 